ABDI: Jurnal Pengabdian dan Pemberdayaan Masyarakat ISSN: 2656-369X (Print), 2684-8570 (Online)

Volume 3 No. 2, Desember 2021

http://abdi.ppj.unp.ac.id/index.php/abdi

Email: abdi@ppj.unp.ac.id

DOI: https://doi.org/10.24036/abdi.v3i2.120

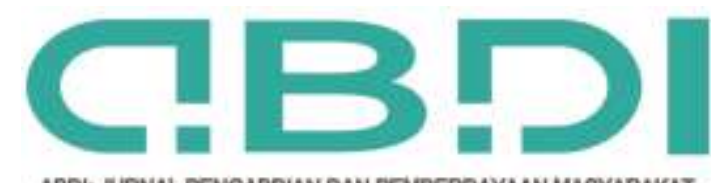

\title{
Pemberdayaan Guru Mata Pelajaran Sosiologi Melalui Literasi Digital Berbasis Quick Response Code di Kecamatan Bissappu Kabupaten Bantaeng
}

\author{
Andi Agustang ${ }^{1}$, Suardi Suardi ${ }^{2}$, Andi Dody May Putra Agustang ${ }^{3}$, Shermina Oruh ${ }^{4}$ \\ ${ }^{1}$ Prodi Ilmu Sosiologi, Universitas Negeri Makassar \\ ${ }^{2}$ Prodi Pendidikan Sosiologi, Universitas Muhammadiyah Makassar \\ ${ }^{3}$ Prodi Pendidikan Sosiologi, Universitas Negeri Makassar \\ ${ }^{4}$ Prodi Kesehatan Masyarakat Universitas Pejuang Republik Indonesia \\ E-mail: andi.agustang@unm.ac.id, suardi@unismuh.ac.id
}

\begin{abstract}
Abstrak
Permasalahan guru yang sangat penting untuk diselesaikan melalui kegiatan pengabdian ini adalah (1) Minimnya pengetahuan dan keterampilan kelompok guru sosiologi dalam membuat quick response code (QRC) pada mata pelajaran Sosiologi, (2) Susahnya siswa mendapatkan materi secara online yang terkait langsung dengan materi pelajaran. Solusi yang bisa dilakukan untuk mengatasi masalah tersebut adalah pelatihan literasi digital berbasis quick response code (QRC) untuk kelompok guru mata pelajaran sosiologi. Hasil kegiatan pengabdian kepada masyarakat yang diperoleh melalui kegiatan literasi digital berbasis quick response code (QRC) untuk kelompok guru mata pelajaran sosiologi dilakukan dalam beberapa tahapan yaitu tahap penyediaan materi, tahap sosialisasi, tahap penyampaian materi, tahap pembagian literasi digital dan tahap gerakan literasi digital. Sedangkan kegiatan pelatihan literasi digital kepada siswa terdiri dari tahap pembuatan jadwal pertemuan, tahap penyampaian materi, tahap penggunaan literasi digital, tahap pembagian literasi digital dan tahap gerakan literasi digital. Hasil yang diperoleh kegiatan ini sangat bermanfaat baik untuk guru mata pelajaran sosiologi dan siswa yang belajar mata pelajaran sosiologi. Literasi digital berbasis quick response code (QRC) sebagai bagian dari gerakan literasi yang dicanangkan oleh pemerintah Kabupaten Bantaeng di tingkat Kecamatan dan dan di tingkat sekolah.

Kata kunci: Literasi Digital, Pemberdayaan, Quick Response Code, Sosiologi.

\section{Abstract}

Teacher problems that are very important to be solved through this service activity are (1) The lack of knowledge and skills of the sociology teacher group in making a quick response code (QRC) in Sociology subjects, (2) The difficulty of students getting online materials that are directly related to the subject matter. The solution that can be done to overcome this problem is digital literacy training based on a quick response code (QRC) for groups of sociology subject teachers. The results of community service activities obtained through QRC-based digital literacy activities for groups of sociology subject teachers are carried out in several stages, namely the stage of providing materials, the stage of socialization, the stage of delivering material, the stage of distributing digital literacy and the stage of the digital literacy movement. Meanwhile, digital literacy training activities for students consist of the stage of making a meeting schedule, the stage of delivering material, the stage of using digital literacy, the stage of distributing digital literacy and the stage of the digital literacy movement. The results obtained from this activity are very useful for both sociology subject teachers and students studying sociology subjects. QRC-based digital literacy as part of the literacy movement launched by the Bantaeng Regency government at the sub-district level and at the school level.
\end{abstract}

Keyword: Digital, Empowerment, Quick Response Codes, Sociology

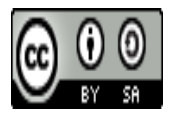

Received: 15 Juni $2021 \quad$ Revised: 9 Agustus $2021 \quad$ Available Online: 27 Agustus 2021 
Andi Agustang, Suardi Suardi, Andi Dody Putra Agustang, Shermina Oruh Pemberdayaan Guru Mata Pelajaran Sosiologi Melalui Literasi Digital Berbasis Quick Response Code di Kecamatan Bissappu Kabupaten Bantaeng

\section{Pendahuluan}

Kasus yang terjadi di pada lokasi mitra di masa new normal sebagai dampak dari pandemic virus corona, proses pembelajaran di semua jenjang pendidikan di lokasi tersebut dan secara umum Kabupaten Bantaeng sesuai kebijakan pemerintah daerah melalui kementerian Pendidikan dan Kebudayaan Kabupaten Bantaeng menginstruksikan pembelajaran dilakukan secara online dengan cara siswa belajar di rumah masing-masing dan guru mengajar di rumah masing-masing.

Permasalah yang muncul yang dihadapi oleh kelompok guru guru mata pelajaran sosiologi yang ada di Kabupaten Bantaeng lebih khusus guru yang ada di Kecamatan Bissappu adalah:

1. Susahnya guru mata pelajaran memberikan materi kepada siswa-siswi secara online karena kendala jaringan internet dalam memberikan pembelajaran lewat zoom atau google meeting karena lokasi mitra yang ada di daerah pegunungan, sehingga guru banyak guru yang melakukan kunjungan ke rumah siswa untuk mengajar siswa.

2. Siswa susah mendapatkan materi yang bisa dipelajari di rumah masing-masing selama masa belajar di rumah, meskipun siswa hampir semuanya memiliki gadget.

Minimnya pengetahuan dan keterampilan guru dalam menggunakan quick response code (QRC) sebagai media literasi digital. Data hasil observasi awal kondisi mitra jumlah dari 7 jumlah kelompok guru mata pelajaran Sosiologi belum ada guru yang menggunakan quick response code (QRC) pada mata pelajaran Sosiologi.

Berbagai masalah yang dihadapi oleh kelompok guru mata pelajaran sosiologi yang menjadi prioritas untuk diselesaikan adalah minimnya pengetahuan dan keterampilan guru dalam menggunakan quick response code (QRC) sebagai media literasi digital. Hal tersebut berdasarkan hasil kesepakatan antara mitra kelompok guru mata pelajaran sosiologi dengan tim pengusul program kemitraan masyarakat, karena masalah tersebut dianggap oleh mitra sebagai masalah yang paling penting untuk dipecahkan melalui program pengabdian kepada masyarakat yang akan dilaksanakan. Alasan lain memilih masalah tersebut untuk diselesaikan karena Indonesia sebagai salah satu memiliki jumlah pengguna internet terbesar di dunia, yang mengalami perkembangan pesat setiap tahun (Puspitaningdyah, 2012). Hasil riset Asosiasi Penyelenggara Jasa Internet Indonesia menunjukkan pengguna Internet di Indonesia 88,1 juta orang tahun 2015 (Febliza \& Okatariani, 2020), tahun 2016 sudah 132,7 juta pengguna internet (Kurnia et al., 2019) dan pada tahun 2017 meningkat sebanyak 132 juta (Wicaksono et al., 2019). Pengguna terbesar pengguna internet adalah usia 10-24 tahun (Kurnia et al., 2019), usia tersebut adalah termasuk usia siswa sekolah. Bahkan hasil penelitian Common Sense Media anak usia dua tahun sudah menggunakan berbagai perangkat digital seperti gadget yang digunakan untuk mengakses game tau film (Kurnia et al., 2019). Hal tersebut terjadi karena generasi millenial seperti siswa memiliki keahlian untuk literasi digital, namun belum mengimbangi dengan pemerolehan informasi untuk pengembangan diri siswa (Sutrisna, 2020), selain itu anak pada dasarnya lebih cepat beradaptasi dengan teknologi dibandingkan dengan orang dewasa, kemampuan tersebut menjadi kebanggan bagi orang tua (Kurnia et al., 2019).

Literasi digital pada masyarakat modern membuat interaksi manusia dengan internet menjadi semakin intens, termasuk penggunaan oleh siswa dan keluarga (Kurnia et al., 2019). Literasi digital bukan hanya diartikan sebagai interaksi dengan media digital namun juga sebagai kontribusi literasi digital dengan perkembangan anak (Kurnia et al., 2019).

Kehadiran gadget mengalihkan perhatian siswa dari buku ke gadget yang dimiliki (Sutrisna, 2020), sehingga membuat siswa jarang membaca buku yang terkait dengan pelajaran, lebih banyak membaca hal-hal yang ada di gadget mereka. Melalui literasi digital dapat membuat tatanan sosial dengan pola pikir dan pandangan yang inovatif, kritis dan kreatif dalam diri siswa, sehingga dapat mengkonstruksi budaya literasi digital perlu melibatkan berbagai elemen untuk berkontribusi memberikan pendidikan literasi digital kepada siswa, termasuk pendidikan informal lebih khusus guru mata pelajaran.

Masa Covid-19 dan masa new normal di kalangan pendidikan banyak memanfaatkan media digital sebagai media pembelajaran, sebagai media belajar di rumah (Sutrisna, 2020), meskipun menggunakan media digital sangat baik untuk siswa dalam mempersiapkan siswa sebagai generasi abad 
Andi Agustang, Suardi Suardi, Andi Dody Putra Agustang, Shermina Oruh Pemberdayaan Guru Mata Pelajaran Sosiologi Melalui Literasi Digital Berbasis Quick Response Code di Kecamatan Bissappu Kabupaten Bantaeng

21 menghadapi era revolusi digital (Sutrisna, 2020), namun perlu didukung oleh guru mata pelajaran untuk berpartisipasi memberikan literasi digital kepada siswa.

Solusi yang bisa dilakukan untuk mengatasi masalah tersebut adalah pelatihan literasi digital berbasis quick response code (QRC) untuk kelompok guru mata pelajaran sosiologi, yang dapat memudahkan guru memberikan buku ajar dan modul mata pelajaran sosiologi secara online kepada siswa masa Covid-19 dan masa new normal melalui gadget yang mereka miliki.

Berbagai sumber belajar yang bisa guru dijadikan literasi digital berbasis quick response code (QRC) sekaligus yang bisa dipelajari siswa pada mata pelajaran sosiologi.

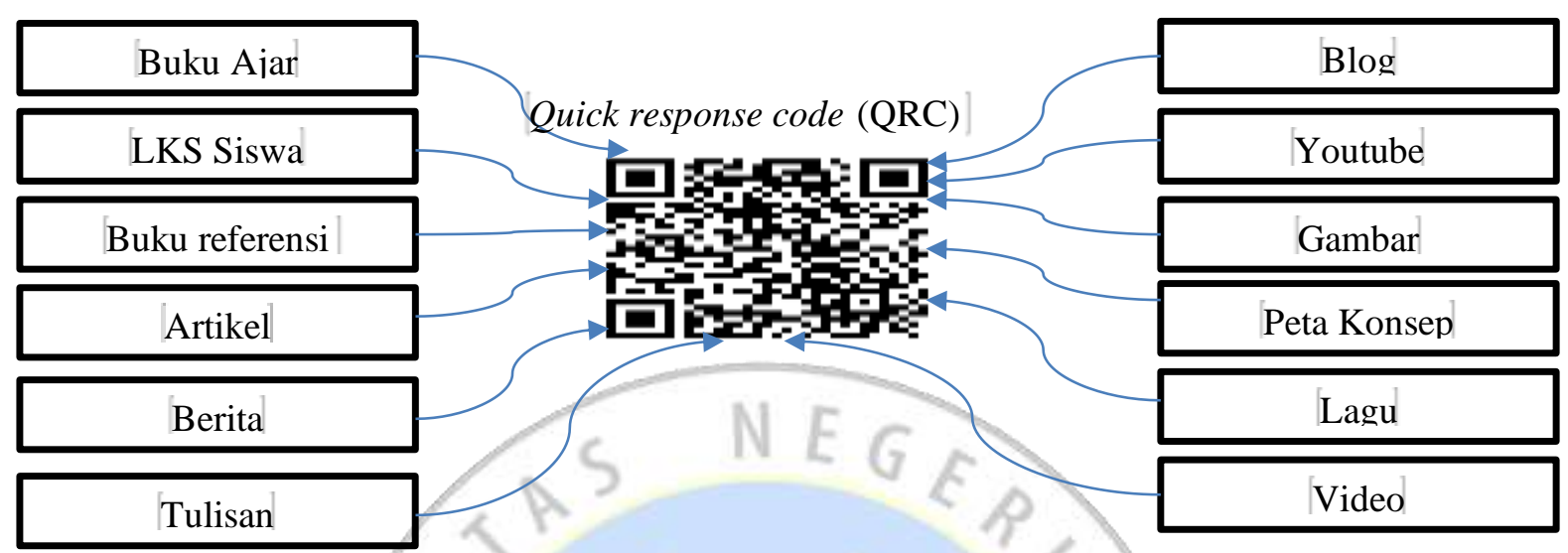

Gambar. 2 Contoh Berbagai sumber belajar yang bisa guru dijadikan literasi digital berbasis quick response code (QRC) pada mata pelajaran sosiologi.

Berbagai sumber belajar yang bisa dijadikan literasi digital berbasis quick response code (QRC) pada mata pelajaran sosiologi dapat dengan mudah diakses oleh siswa melalui gadget yang dimiliki oleh siswa.

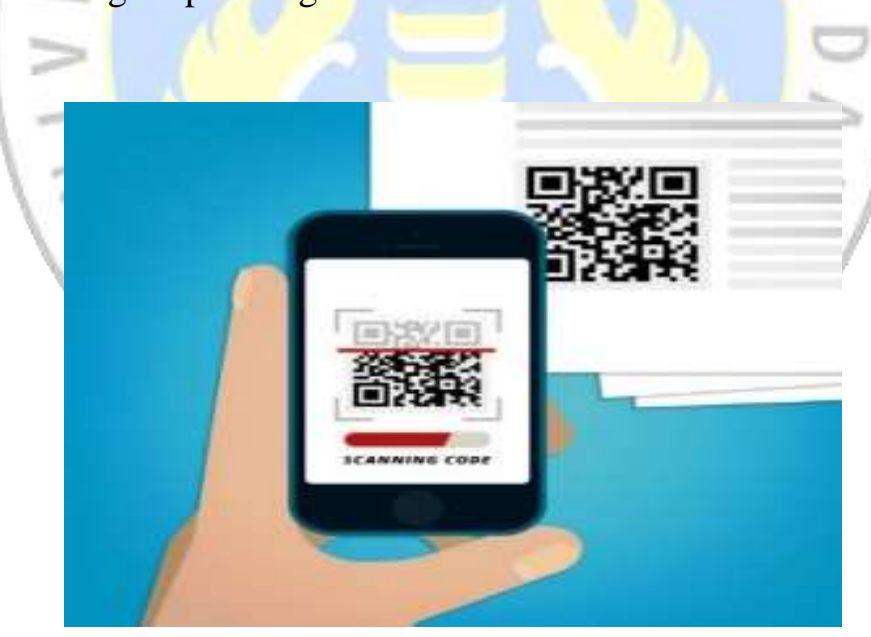

Gambar 3. Cara untuk siswa mengakses materi mata pelajaran sosiologi melalui gadget yang dimiliki oleh siswa.

Setelah siswa melakukan scan quick response code (QRC) pada mata pelajaran sosiologi maka akan langsung terkoneksi secara online pada materi yang diberikan oleh guru baik materi pada bahan ajar, LKS siswa, buku referensi, artikel, berita, atau tulisan guru, blog, youtube, gambar, peta konsep, lagu atau video yang berkaitan dengan pada mata pelajaran sosiologi sehingga siswa mendapatkan materi pelajaran secara mudah dari guru.

Program pengabdian kepada masyarakat tersebut juga sebagai bentuk gerakan literasi untuk guru dan siswa pada masa pandemic covid 19 (Sutrisna, 2020) dan masa new normal. Dengan gerakan literasi dapat menciptakan pola pikir yang kreatif dalam diri siswa di masa pandemic covid 19 (Sutrisna, 2020). Dengan quick response code (QRC) guru mudah memberikan informasi yang 
Andi Agustang, Suardi Suardi, Andi Dody Putra Agustang, Shermina Oruh Pemberdayaan Guru Mata Pelajaran Sosiologi Melalui Literasi Digital Berbasis Quick Response Code di Kecamatan Bissappu Kabupaten Bantaeng

dibutuhkan oleh siswa, hanya dengan melakukan proses scanning, kemudian melakukan pemindaian data melalui media dari kamera handphone yang dimiliki (Anastasia, Istiadi, dan Hidayat, 2010).

Penggunaan quick response code (QRC) sangat efektif digunakan untuk berbagai kepentingan termasuk pada bidang pendidikan. Penggunaan dalam bidang pendidikan relatiF masih baru, quick response code (QRC) digunakan untuk pembelajaran seluler (Bonifácio, 2012), digunakan sebagai sistem pembelajaran (Lai et al., 2013), implementasi pendidikan di sekolah (C. Law \& So, 2010), mengkonfirmasi kehadiran mahasiswa saat kuliah (Masalha \& Hirzallah, 2014), mendesain ulang materi kuliah (Durak et al., 2016), pembelajaran di kelas (Rikala \& Kankaanranta, 2012), kegiatan pembelajaran di sekolah (Nagla et al., 2017), menjaga dokumen pendidikan, keamanan dan menghindari duplikasi (Goyal et al., 2016), melihat dan merekam kehadiran siswa (Baban, 2014), menonton klip video keterampilan oleh pelajar (Tracey et al., 2013), pembelajaran mata kuliah kedokteran (Traser et al., 2015), mendorong interaksi siswa selama proses pembelajaran (R. Law, 2012), sarana penyediaan informasi dengan menghubungkan berbagai media (Mawaddah et al., 2018), meningkatkan pengetahuan siswa tentang spesies tumbuhan melalui akses situs web, teks, video (Patil, 2020), memudahkan siswa melihat halaman web (Susono \& Shimomura, 2006), digunakan praktik di bidang medis (Dental, 2017), membantu guru dalam menyampaikan informasi kepada siswa (Abualnadi et al., 2018), pembelajaran aktif untuk siswa yang dapat meningkatkan keterlibatan siswa dan rasa ingin tahu siswa (Somerall \& Roche, 2020). Semua hasil penelitian yang menggunakan quick response code $(\mathrm{QRC})$ memperoleh hasil yang positif sehingga quick response code $(\mathrm{QRC})$ diharapkan menjadi media literasi digital yang digunakan oleh guru mata pelajaran sosiologi kepada siswa terutama pada masa Covid-19 dan masa new normal.

Kecerdasan guru dalam membuat literasi digital sangat penting untuk menunjang proses pembelajaran mata pelajaran sosiologi untuk siswa selama masa belajar di rumah, sehingga sasaran pelatihan literasi digital berbasis quick response code (QRC) untuk guru mata pelajaran sosiologi untuk siswa di Kabupaten Bantaeng adalah:

a. Memberikan keterampilan kepada kelompok guru mata pelajaran sosiologi membuat literasi digital berbasis quick response code (QRC).

b. Menciptakan gerakan literasi digital berbasis quick response code (QRC) untuk kelompok mata pelajaran sosiologi.

Pengabdian kepada masyarakat terkait dengan literasi digital keluarga berbasis quick response code (QRC) perna dilakukan oleh peneliti pada tahun 2020 dengan judul pemberdayaan masyarakat desa melalui literasi digital berbasis quick response code (QRC) di Desa Bontojai Kecamatan Bissappu Kabupaten Bantaeng. Hasil yang diperoleh dari kegiatan pengabdian kepada masyarakat yang dilakukan memberikan kemudahan kepada masyarakat dalam mengakses informasi terkait pendidikan, meningkatnya frekuensi membaca menggunakan handphone setiap hari, dan menciptakan gerakan literasi digital berbasis quick response code (QRC) (Nursalam, N., Suardi, S., Syarifuddin, S., Mutiara, I. A., \& Herdianty, R. (2020).

\section{Metode Pelaksanaan}

Metode pelaksanaan program pengabdian kepada masyarakat akan diberikan pelatihan dan pendampingan kepada kepada kelompok guru mata pelajaran sosiologi.

1. Pelatihan literasi digital berbasis quick response code $(\mathrm{QRC})$ untuk kelompok guru mata pelajaran.

a. Tahap Pertama penyediaan materi. Tim pengabdian kepada masyarakat menyediakan literasi digital berbasis quick response code (QRC) yang diberikan kepada guru mata pelajaran sosiologi

b. Tahap kedua melakukan Sosialisasi. Tim pengabdian kepada masyarakat melakukan sosialisasi pelaksanaan kegiatan ke Kantor Kecamatan Bissappu Kabupaten Bantaeng, sebelum melakukan kegiatan pengabdian kepada masyarakat

c. Tahap ketiga menyampaikan materi. Tim pengabdian kepada masyarakat menyampaikan literasi digital berbasis quick response code (QRC) kepada guru mata pelajaran sosiologi 
Andi Agustang, Suardi Suardi, Andi Dody Putra Agustang, Shermina Oruh Pemberdayaan Guru Mata Pelajaran Sosiologi Melalui Literasi Digital Berbasis Quick Response Code di Kecamatan Bissappu Kabupaten Bantaeng

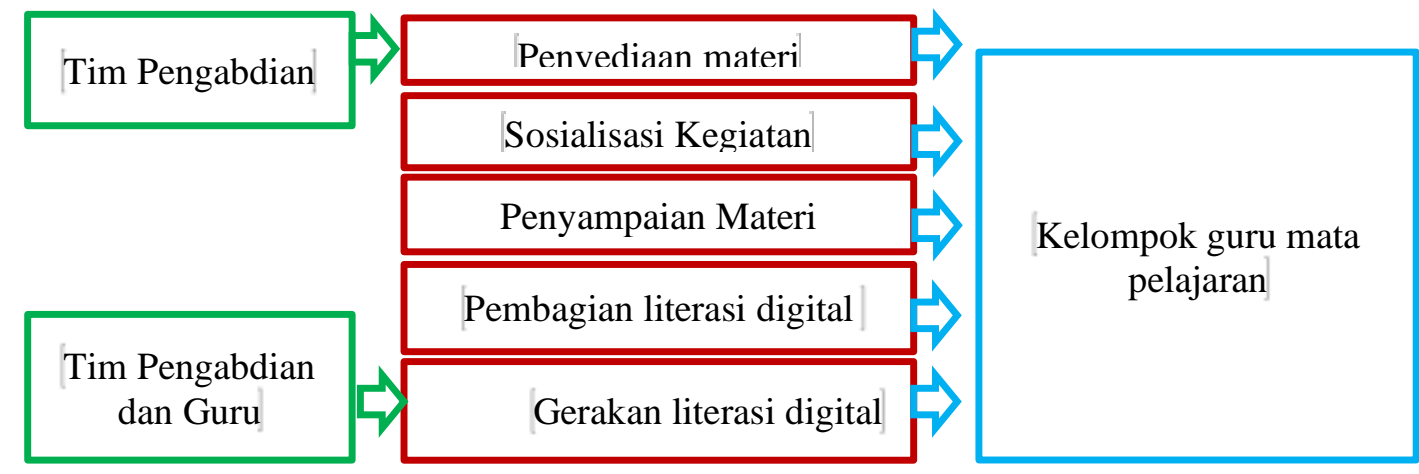

Gambar. 4. Aktivitas pelatihan literasi digital berbasis quick response code (QRC) untuk kelompok guru mata pelajaran sosiologi.

2. Pelatihan literasi digital berbasis quick response code (QRC) kepada siswa

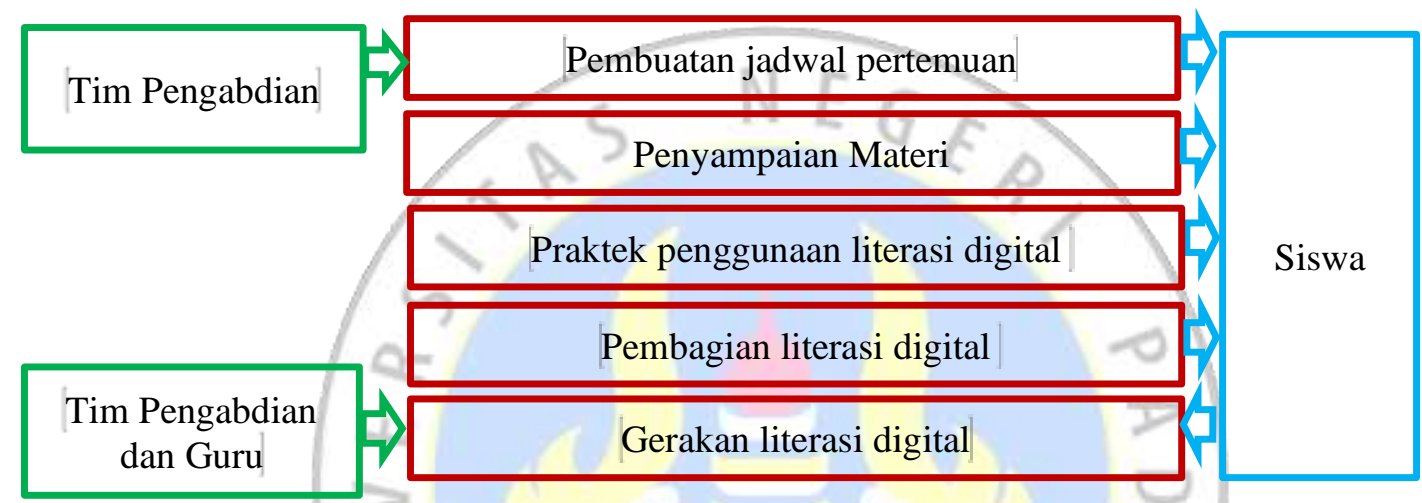

Gambar. 5. Aktivitas pelatihan penggunaan literasi digital berbasis quick response code (QRC) kepada siswa

a. Tahap Pertama pembuatan jadwal pertemuan. Tim pengabdian kepada masyarakat dan guru mata pelajaran sosiologi membuat jadwal pertemuan tim pengabdian kepada masyarakat dengan siswa

b. Tahap kedua penyampaian materi. Tim pengabdian kepada masyarakat dibantu oleh guru mata pelajaran sosiologi menyampaikan literasi digital berbasis quick response code (QRC) kepada siswa

c. Tahap ketiga praktek penggunaan literasi digital berbasis quick response code (QRC). Tim pengabdian kepada masyarakat dibantu oleh guru Praktek penggunaan literasi digital berbasis quick response code (QRC) kepada siswa menggunakan smartphone.

d. Tahap keempat pembagian literasi digital berbasis quick response code (QRC). Tim pengabdian kepada masyarakat dan guru sosiologi dengan membagikan literasi digital berbasis quick response code (QRC) mata pelajaran sosiologi kepada siswa-siswi agar dapat dibawa ke rumah untuk di tempel di rumah masing-masing

e. Tahap Kelima gerakan literasi digital berbasis quick response code (QRC) Tim pengabdi, guru sosiologi dan siswa berkomitmen untuk terus melakukan gerakan literasi digital berbasis quick response code $(\mathrm{QRC})$.

Partisipasi mitra kelompok guru mata pelajaran sosiologi dalam Program pengabdian kepada masyarakat yang akan dilakukan adalah:

a. Kesediaan mengikuti program kegiatan pengabdian kepada masyarakat

b. Memberikan masukan bentuk literasi digital yang sangat urgen untuk diberikan kepada siswa.

c. Mengatur jadwal pertemuan tim pengabdian kepada masyarakat dengan siswa di sekolah

d. Terlibat dalam pelaksanaan sosialisasi pelatihan penggunaan literasi digital berbasis quick response code (QRC) kepada siswa. 
Andi Agustang, Suardi Suardi, Andi Dody Putra Agustang, Shermina Oruh Pemberdayaan Guru Mata Pelajaran Sosiologi Melalui Literasi Digital Berbasis Quick Response Code di Kecamatan Bissappu Kabupaten Bantaeng

e. Ikut terlibat dalam gerakan literasi digital berbasis quick response code (QRC).

Pelaksanaan program pengabdian kepada masyarakat dilakukan melalui pemberian angket kepada kelompok guru mata pelajaran sosiologi dan siswa, untuk mengetahui respon guru guru mata pelajaran sosiologi dan siswa terhadap program pengabdian kepada masyarakat yang dilakukan. Keberhasilan program pengabdian kepada masyarakat jika $85 \%$ dari total responden menganggap program pengabdian kepada masyarakat yang dilakukan bermanfaat atau sangat bermanfaat. Angket yang digunakan adalah angket tertutup dengan menggunakan skala Likert yaitu sangat bermanfaat (5), Bermanfaat (4), biasa-biasa saja (3), Kurang bermanfaat (2), dan Tidak bermanfaat (1).

Teknik pengelolaan data hasil angket terdiri dari verifikasi kuesioner, tabulasi data kuesioner dan persentase data kuesioner (Sugiyono, 2011). Rumus menghitung persentase, yaitu:

$$
\frac{\mathrm{n} \times 100}{\mathrm{~N}}
$$

Dimana:

$\%$ : Persentase

$\mathrm{n} \quad$ : Nilai yang diperoleh

$\mathrm{N} \quad$ : Jumlah seluruh nilai

100 : Bilangan tetap

Kriteria penafsiran data untuk kepentingan penelitian ini merujuk pada pendapat (Sugiyono, 2011), dapat dilihat pada tabel 2 berikut:

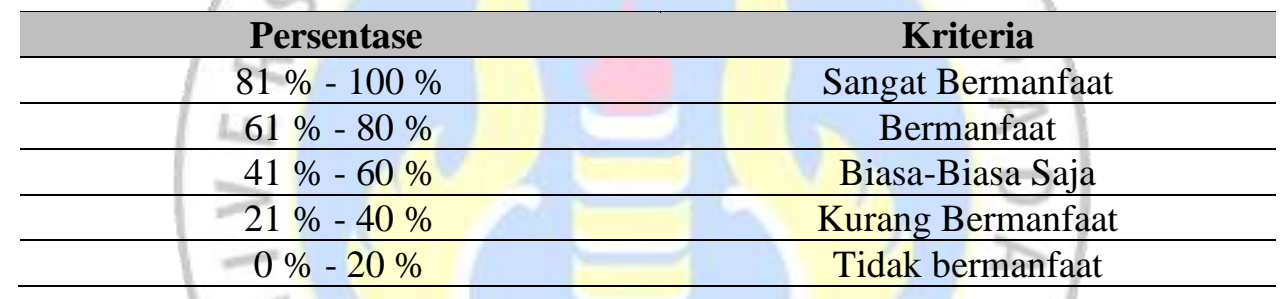

Keberlanjutan kegiatan program pengabdian kepada masyarakat melalui literasi digital berbasis quick response code (QRC) akan terus dilakukan oleh kelompok guru mata pelajaran sosiologi sebagai bagian dari gerakan literasi yang dicanangkan oleh pemerintah Kabupaten Bantaeng melalui Dinas Pendidikan dan Kebudayaan dan gerakan literasi di tingkat Desa dan tingkat Sekolah.

\section{Hasil dan Pembahasan}

Pelaksanaan program pengabdian kepada masyarakat dengan memberikan pelatihan dan pendampingan kepada kepada kelompok guru mata pelajaran sosiologi. Bentuk pelatihan yang diberikan mencakup:

\subsection{Pelatihan literasi digital berbasis quick response code (QRC) untuk kelompok guru mata pelajaran Sosiologi.}

Pelatihan literasi digital berbasis quick response code (QRC) untuk kelompok guru mata pelajaran Sosiologi dilakukan pada tiga sekolah Swasta di Kecamatan Bissappu Kabupaten Bantaeng yaitu Madrasah Aliyah (MA) Muhammadiyah Panaikang, Madrasah Aliyah (MA) Ma'arif Panaikang dan Madrasah Aliyah (MA) Ma'arif Campagaloe. Setiap sekolah diwakili oleh satu guru mata pelajaran sosiologi sehingga guru yang diberdayakan di dalam program pengabdian kepada masyarakat sebanyak tiga orang guru. Tahapan pelaksanaan kegiatan pengabdian kepada masyarakat melalui pelatihan literasi digital berbasis quick response code (QRC) untuk kelompok guru mata pelajaran Sosiologi yaitu:

a. Tahap Pertama penyediaan materi. Tim pengabdian kepada masyarakat menyediakan literasi digital berbasis quick response code (QRC) yang diberikan kepada guru mata pelajaran sosiologi yaitu literasi digital buku ajar mata pelajaran sosiologi mulai kelas X, kelas XI dan kelas XII dari berbagai 
Andi Agustang, Suardi Suardi, Andi Dody Putra Agustang, Shermina Oruh Pemberdayaan Guru Mata Pelajaran Sosiologi Melalui Literasi Digital Berbasis Quick Response Code di Kecamatan Bissappu Kabupaten Bantaeng

penulis dan penerbit sehingga dapat memberikan pilihan yang luas bagi guru dan siswa dalam belajar mata pelajaran sosiologi sesuai tingkatan kelas siswa. Selain itu juga tersedia modul mata pelajaran sosiologi yang bisa digunakan oleh guru dan siswa dalam belajar mulai kelas X, kelas XI dan kelas XII. Pada modul tersebut sudah termuat tujuan pembelajaran, uraian materi, rangkuman materi, penugasan mandiri, latihan soal dan penilaian diri pada setiap bab materi. Sehingga sangat praktis dan efektif digunakan oleh guru dan siswa dalam melakukan proses pembelajaran pada mata pelajaran sosiologi dalam belajar online di rumah maupun belajar secara tatap muka di sekolah.

\begin{tabular}{|c|c|c|c|c|}
\hline 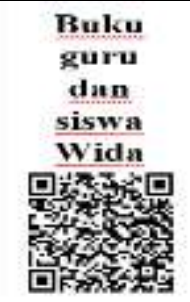 & 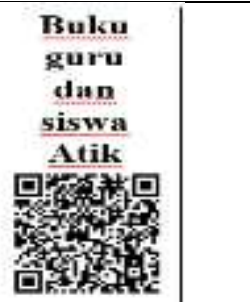 & 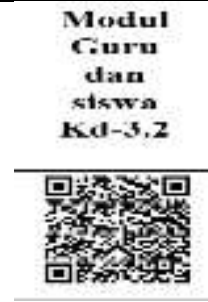 & 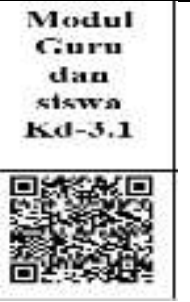 & 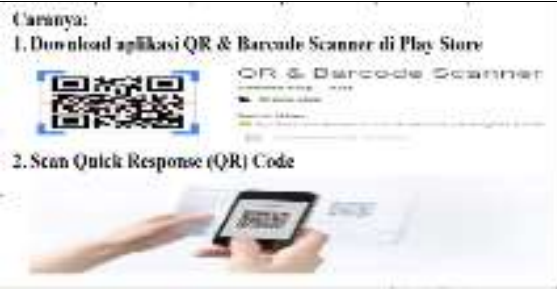 \\
\hline \multicolumn{2}{|c|}{$\begin{array}{c}\text { Gambar 6. Buku ajar } \\
\text { literasi digital berbasis } \\
\text { quick response code (QRC) } \\
\text { mata pelajaran sosiologi }\end{array}$} & \multicolumn{2}{|c|}{$\begin{array}{l}\text { Gambar 7. Modul } \\
\text { literasi digital berbasis } \\
\text { quick response code } \\
\text { (QRC) mata pelajaran } \\
\text { sosiologi }\end{array}$} & $\begin{array}{c}\text { Gambar 8. Cara penggunaan } \\
\text { buku ajar dan modul literasi } \\
\text { digital berbasis quick response } \\
\text { code (QRC) mata pelajaran } \\
\text { sosiologi }\end{array}$ \\
\hline
\end{tabular}

Literasi digital berbasis quick response code (QRC) mata pelajaran sosiologi dalam bentuk buku ajar dan modul mata pelajaran sosiologi berdasarkan kebutuhan guru dan siswa yang paling mendesak adalah buku ajar dan modul yang bisa digunakan dalam melakukan proses pembelajaran di sekolah maupun di rumah secara praktis, sehingga buku ajar dan modul yang menjadi prioritas utama dalam kegiatan pengabdian.

b. Tahap kedua melakukan Sosialisasi. Tim pengabdian kepada masyarakat melakukan sosialisasi pelaksanaan kegiatan ke Kantor Kecamatan Bissappu Kabupaten Bantaeng, sebelum melakukan kegiatan pengabdian kepada masyarakat di Madrasah Aliyah (MA) Muhammadiyah Panaikang, Madrasah Aliyah (MA) Ma'arif Panaikang dan Madrasah Aliyah (MA) Ma'arif Campagaloe, sekaligus menjelaskan mekanisme penggunaan literasi digital berbasis quick response code (QRC) pada mata pelajaran sosiologi. Hal tersebut mendapatkan respon positif dari Bapak Poniman S, SS selaku Camat Bissappu Kabupaten Bantaeng. Menurutnya kegiatan pengabdian yang dilakukan sangat relevan dengan situasi pandemi Covid 19 yang menganjurkan siswa belajar di rumah dan adanya keluhan dari siswa keterbatasan buku ajar dan modul mata pelajaran sosiologi.

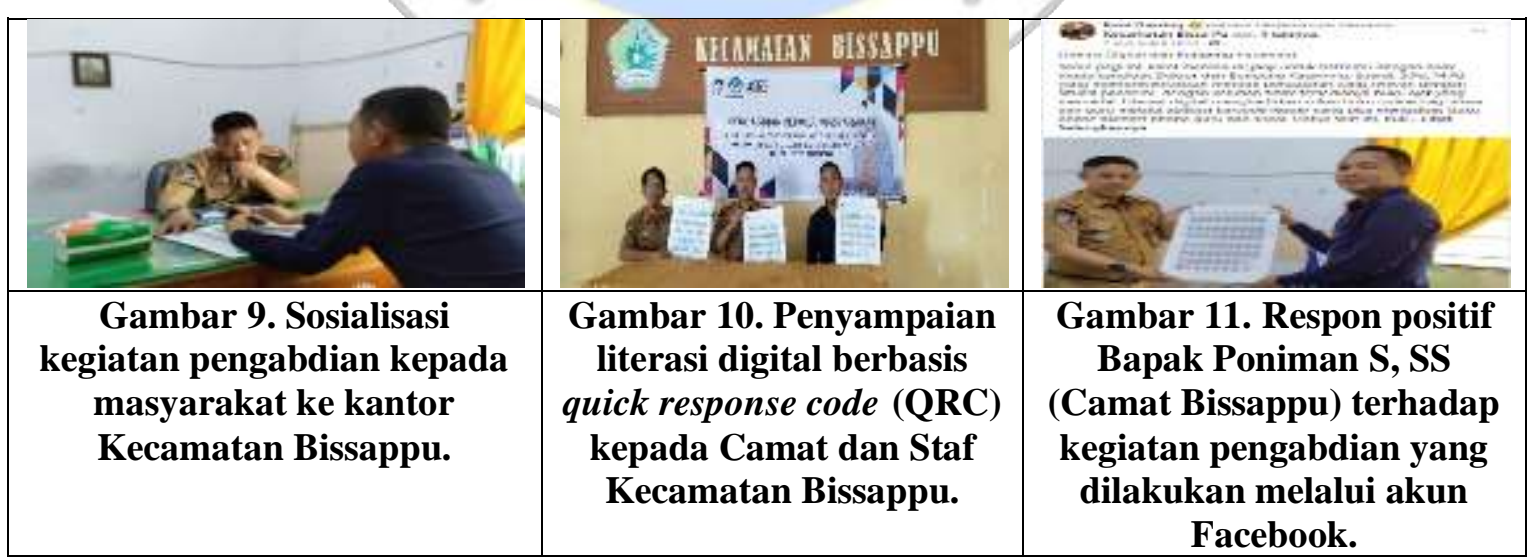

c. Tahap ketiga menyampaikan materi. Tim pengabdian kepada masyarakat menyampaikan literasi digital berbasis quick response code (QRC) kepada guru mata pelajaran sosiologi Madrasah Aliyah (MA) Muhammadiyah Panaikang, guru mata pelajaran sosiologi Madrasah Aliyah (MA) Ma'arif Panaikang dan guru mata pelajaran sosiologi Madrasah Aliyah (MA) Ma'arif Campagaloe. Ketiga 
Andi Agustang, Suardi Suardi, Andi Dody Putra Agustang, Shermina Oruh Pemberdayaan Guru Mata Pelajaran Sosiologi Melalui Literasi Digital Berbasis Quick Response Code di Kecamatan Bissappu Kabupaten Bantaeng

sekolah tersebut adalah sekolah yang berada di Kecamatan Bissappu Kabupaten Bantaeng yang mengajarkan mata pelajaran sosiologi dalam kurikulum sekolah. Penyampaian materi literasi digital berbasis quick response code (QRC) dilakukan di sekolah dan di rumah guru dengan menpertimbangkan protokol kesehatan di masa new normal, karena ada sekolah yang sudah mulai aktif melakukan proses pembelajaran di sekolah namun dengan pembatasan dan mematuhi protokol kesehatan di masa new normal dan ada juga yang melakukan proses pembelajaran secara online sehingga pelaksanaan kegiatan pengabdian dilakukan secara individual bertemu langsung dengan guru di sekolah atau di rumah guru.
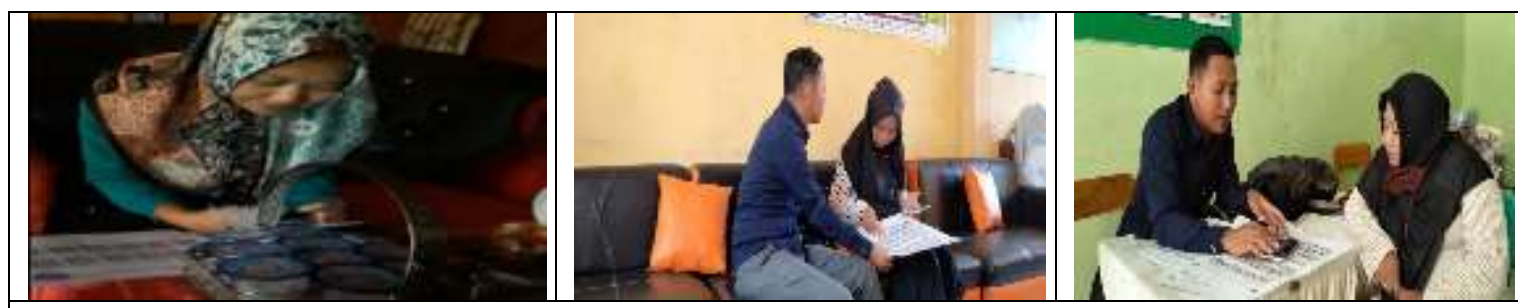

Gambar 12. Penyampaian dan praktek literasi digital berbasis quick response code (QRC) kepada guru mata pelajaran sosiologi Madrasah Aliyah (MA) Muhammadiyah

Panaikang, guru Madrasah Aliyah (MA) Ma'arif Panaikang dan guru Madrasah Aliyah (MA) Ma'arif Campagaloe

d. Tahap keempat pembagian literasi digital berbasis quick response code (QRC). Tim pengabdian kepada masyarakat kemudian membagikan literasi digital berbasis quick response code (QRC) mata pelajaran sosiologi ke guru-guru sosiologi sebanyak 2 example agar dapat disimpan di sekolah dan rumah masing sehingga ketika guru membutuhkan materi atau modul mata pelajaran sosiologi setiap guru dapat dengan mudah langsung mengakses literasi digital berbasis quick response code (QRC) mata pelajaran sosiologi.

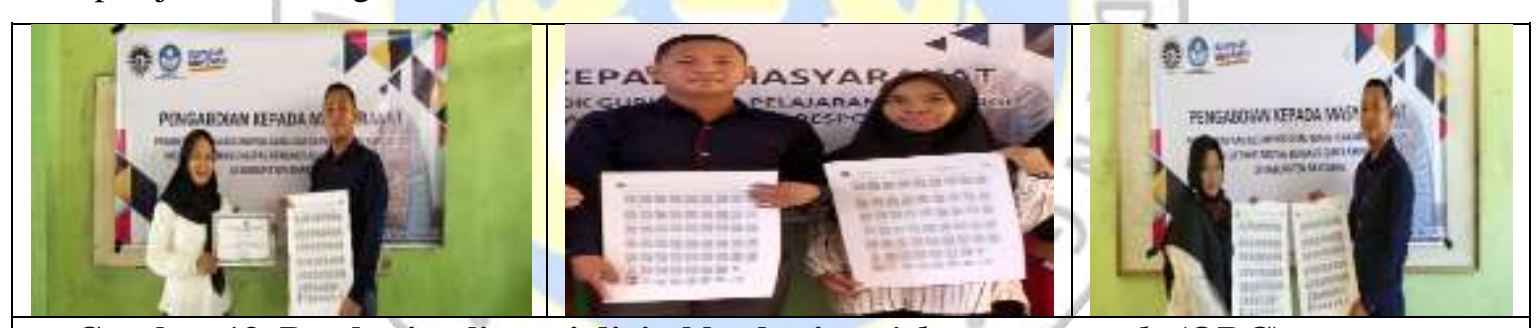

Gambar 13. Pemberian literasi digital berbasis quick response code (QRC) guru mata pelajaran sosiologi Madrasah Aliyah (MA) Muhammadiyah Panaikang, guru Madrasah Aliyah (MA) Ma'arif Panaikang dan guru Madrasah Aliyah (MA) Ma'arif Campagaloe

e. Tahap Kelima gerakan literasi digital berbasis quick response code (QRC). Tim pengabdi dan guru sosiologi berkomitmen untuk terus melakukan gerakan literasi digital berbasis quick response code (QRC) dengan menambah variasi materi-materi yang dibutuhkan oleh siswa, agar dapat membantu siswa dalam melakukan proses pembelajaran pada mata pelajaran sosiologi.

\subsection{Pelatihan literasi digital berbasis quick response code (QRC) kepada siswa}

a. Tahap Pertama pembuatan jadwal pertemuan. Tim pengabdian kepada masyarakat dan guru mata pelajaran sosiologi membuat jadwal pertemuan tim pengabdian kepada masyarakat dengan siswa untuk menyampaikan literasi digital berbasis quick response code (QRC) kepada siswa. Hasil kesepakatan tim pengabdian kepada masyarakat dan guru mata pelajaran sosiologi untuk siswa Madrasah Aliyah (MA) Ma'arif Panaikang dan Madrasah Aliyah (MA) Ma'arif Campagaloe dilakukan di sekolah bersama dengan guru mata pelajaran sosiologi, karena kedua sekolah tersebut melakukan proses pembelajaran secara tatap muka dengan pembatasan siswa. Sedangkan untuk Madrasah Aliyah (MA) Muhammadiyah Panaikang hanya dilakukan oleh guru mata pelajaran 
Andi Agustang, Suardi Suardi, Andi Dody Putra Agustang, Shermina Oruh Pemberdayaan Guru Mata Pelajaran Sosiologi Melalui Literasi Digital Berbasis Quick Response Code di Kecamatan Bissappu Kabupaten Bantaeng

sosiologi kepada siswa karena sekolah tersebut membelajarkan siswa secara online sehingga siswa tidak ada di sekolah.

b. Tahap kedua penyampaian materi. Tim pengabdian kepada masyarakat dibantu oleh guru mata pelajaran sosiologi menyampaikan literasi digital berbasis quick response code (QRC) kepada siswa dengan menggunakan smartphone sebagai media untuk, dengan terlebih dahulu mendownload aplikasi $Q R$ \& Barcode Scanner di Play Store, (2) Membagikan contoh literasi digital berbasis quick response code $(\mathrm{QRC})$ pada mata pelajaran sosiologi kepada setiap siswa.
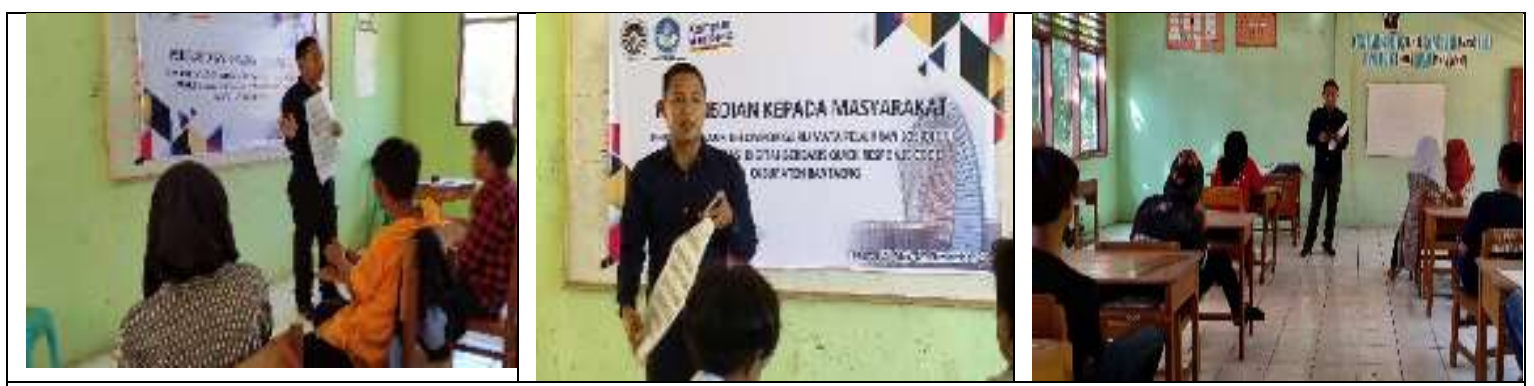

Gambar 14. Penyampaian literasi digital berbasis quick response code (QRC) kepada

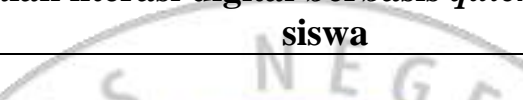

c. Tahap ketiga praktek penggunaan literasi digital berbasis quick response code (QRC). Tim pengabdian kepada masyarakat dibantu oleh guru Praktek penggunaan literasi digital berbasis quick response code $(\mathrm{QRC})$ kepada siswa menggunakan smartphone. Cara menggunakan literasi digital berbasis quick response code (QRC) pada mata pelajaran sosiologi sangat mudah dilakukan oleh siswa, karena siswa hanya melakukan scan quick response code (QRC) yang telah dibagikan yang memuat buku ajar dan modul mata pelajaran sosiologi, secara otomatis akan langsung terkoneksi secara online pada buku mata pelajaran sosiologi atau modul mata pelajaran sosiologi.

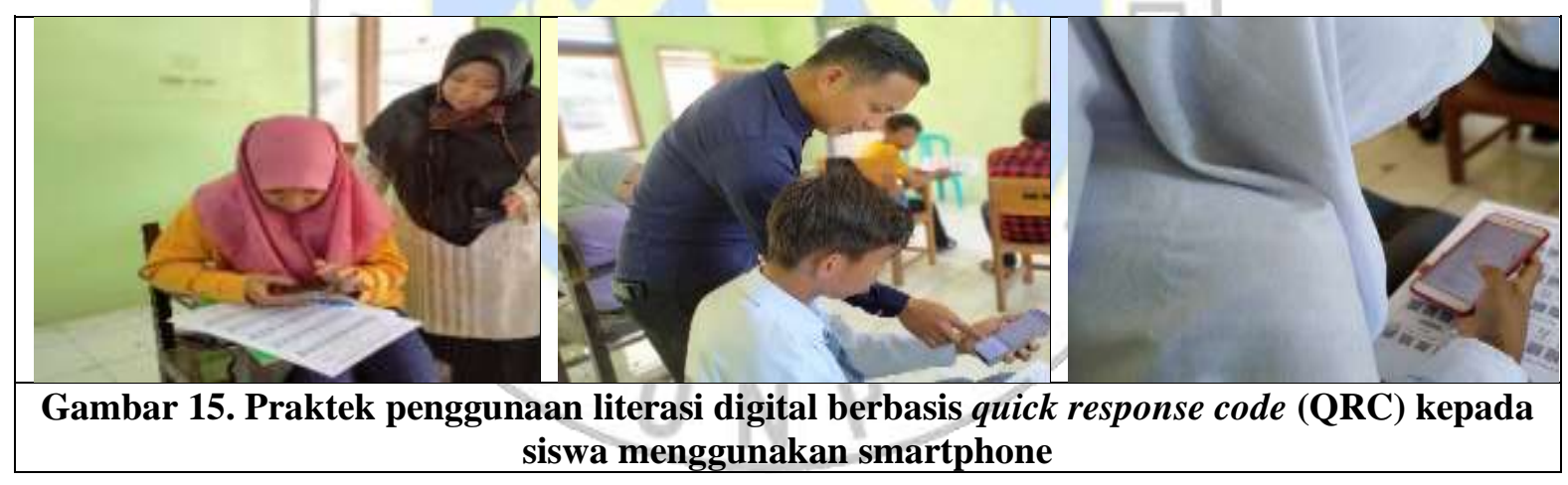

d. Tahap keempat pembagian literasi digital berbasis quick response code (QRC). Tim pengabdian kepada masyarakat dan guru sosiologi dengan membagikan literasi digital berbasis quick response code (QRC) mata pelajaran sosiologi kepada siswa-siswi agar dapat dibawa ke rumah untuk di tempel di rumah masing-masing sehingga ketika siswa membutuhkan materi atau modul mata pelajaran sosiologi setiap siswa dapat dengan mudah langsung mengakses literasi digital berbasis quick response code (QRC) mata pelajaran sosiologi. 
Andi Agustang, Suardi Suardi, Andi Dody Putra Agustang, Shermina Oruh Pemberdayaan Guru Mata Pelajaran Sosiologi Melalui Literasi Digital Berbasis Quick Response Code di Kecamatan Bissappu Kabupaten Bantaeng

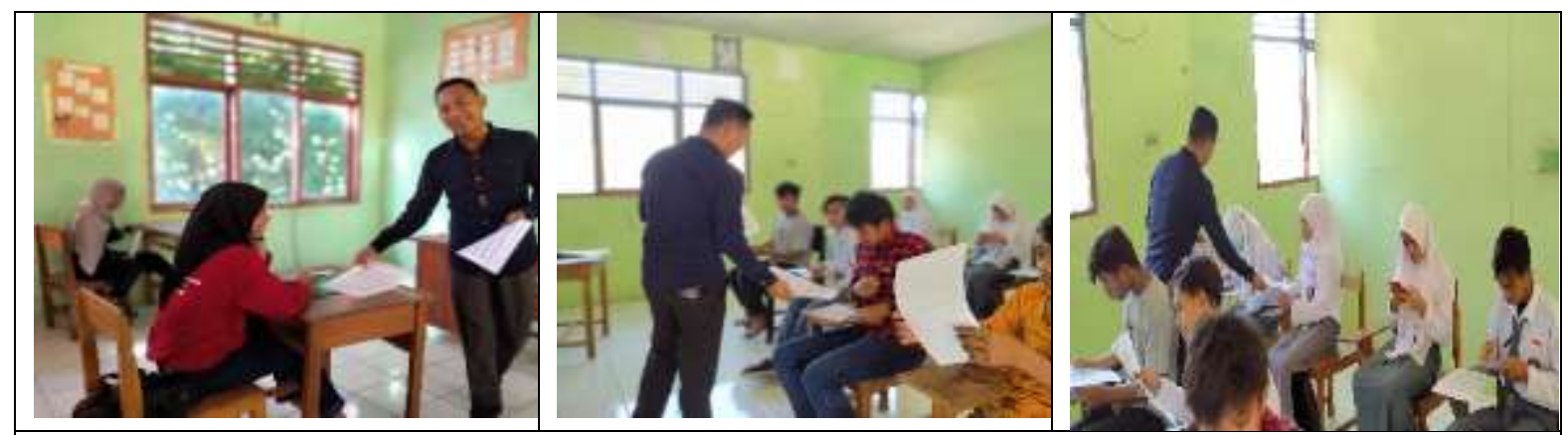

Gambar 16. Pembagian literasi digital berbasis quick response code (QRC) siswa Madrasah Aliyah (MA) Ma'arif Panaikang dan siswa Madrasah Aliyah (MA) Ma'arif Campagaloe.

e. Tahap Kelima gerakan literasi digital berbasis quick response code (QRC). Tim pengabdi, guru sosiologi dan siswa berkomitmen untuk terus melakukan gerakan literasi digital berbasis quick response code $(\mathrm{QRC})$ dengan menambah variasi materi-materi yang dibutuhkan oleh siswa, agar dapat membantu siswa dalam melakukan proses pembelajaran pada mata pelajaran sosiologi.

Pelaksanaan program pengabdian kepada masyarakat yang telah dilakukan melalui literasi digital berbasis quick response code (QRC) pada mata pelajaran sosiologi mendapatkan respon positif dari semua kalangan yang terlibat dalam kegiatan pengabdian mual dari Camat Bissappu Kabupaten Bantaeng, guru-guru mata pelajaran sosiologi, siswa dan siswi yang belajar mata pelajaran sosiologi, bahkan guru mata pelajaran lain yang juga ingin menggunakan literasi digital berbasis quick response code $(\mathrm{QRC})$ sesuai mata pelajaran yang diajar.

Berdasarkan hasil angket yang telah diberikan kepada Camat Bissappu Kabupaten Bantaeng, guru-guru mata pelajaran sosiologi, siswa dan siswi yang belajar mata pelajaran sosiologi, dari total responden 35 yang terdiri Camat Bissappu Kabupaten Bantaeng 1 orang, Guru mata pelajaran sosiologi sebanyak 3 orang, dan siswa yang belajar mata pelajaran sosiologi sebanyak 31 orang. Angket yang diberikan bertujuan untuk mengetahui respon pemerintah, guru guru mata pelajaran sosiologi dan siswa yang belajar mata pelajaran sosiologi terhadap literasi digital berbasis quick response code (QRC) pada mata pelajaran sosiologi. Berdasarkan hasil angket pemerintah, guru guru mata pelajaran sosiologi dan siswa yang belajar mata pelajaran sosiologi terhadap literasi digital berbasis quick response code (QRC) pada mata pelajaran sosiologi telah mencapai hasil yang maksimal sesuai dengan indikator pencapaian kegiatan pengabdian kepada masyarakat yaitu $85 \%$ dari 35 total responden menganggap program pengabdian kepada masyarakat yang dilakukan sangat bermanfaat baik untuk guru mata pelajaran sosiologi dan siswa yang belajar mata pelajaran sosiologi. Berikut tabel persentase respon positif pemerintah, guru guru mata pelajaran sosiologi dan siswa yang belajar mata pelajaran sosiologi terhadap literasi digital berbasis quick response code $(\mathrm{QRC})$ pada mata pelajaran sosiologi:

Tabel 1. Kebermanfaatan Literasi digital berbasis quick response code (QRC) pada mata pelajaran sosiologi

\begin{tabular}{lccc}
\hline \multirow{2}{*}{ Jenis Responden } & $\begin{array}{c}\text { Kebermanfaatan Literasi digital } \\
\text { berbasis quick response code }(\mathbf{Q R C}) \\
\text { pada mata pelajaran sosiologi }\end{array}$ & $\begin{array}{c}\text { Total } \\
\text { Responden }\end{array}$ \\
\cline { 2 - 4 } & Ya & Tidak & \\
\hline Pemerintah & 1 & 0 & 3 \\
\hline Guru mata pelajaran sosiologi & 3 & 0 & 31 \\
\hline $\begin{array}{l}\text { Siswa yang belajar mata pelajaran } \\
\text { sosiologi }\end{array}$ & 31 & 0 & 301 \\
\hline Jumlah Populasi & 35 & 0 & $100 \%$ \\
\hline Persentase & $100 \%$ & $0 \%$ & 1 \\
\hline
\end{tabular}


Andi Agustang, Suardi Suardi, Andi Dody Putra Agustang, Shermina Oruh Pemberdayaan Guru Mata Pelajaran Sosiologi Melalui Literasi Digital Berbasis Quick Response Code di Kecamatan Bissappu Kabupaten Bantaeng

Berdasarkan hasil pengamatan tim pengabdian kepada masyarakat dalam kegiatan pelatihan literasi digital berbasis quick response code (QRC) semua guru mata pelajaran sosiologi atau $100 \%$ dari 3 orang guru sudah memiliki keterampilan menggunakan literasi digital berbasis quick response code (QRC) pada mata pelajaran Sosiologi, sedangkan untuk siswa dan siswi yang belajar mata pelajaran sosiologi $96.77 \%$ atau 30 orang siswa sudah dapat menggunakan literasi digital berbasis quick response code $(\mathrm{QRC})$ pada mata pelajaran sosiologi dari 31 orang siswa. 1 orang siswa yang tidak bisa hanya karena tidak memiliki smartphone sehingga belum bisa melakukan praktek literasi digital berbasis quick response code (QRC) pada mata pelajaran Sosiologi.

Partisipasi guru mata pelajaran sosiologi dalam Program pengabdian kepada masyarakat yang akan dilakukan adalah

a. Guru mata pelajaran sosiologi bersedia untuk mengikuti program kegiatan pengabdian kepada masyarakat mulai sejak perencanaan kegiatan pengabdian pada tahun 2020, pelaksanaan kegiatan pengabdian pada tahun 2021 sampai pada akhir kegiatan pengabdian di akhir tahun 2021

b. Guru mata pelajaran sosiologi memberikan masukan bentuk literasi digital yang sangat urgen untuk diberikan kepada siswa yaitu literasi digital berbasis quick response code (QRC) buku ajar dan modul mata pelajaran sosiologi.

c. Guru mata pelajaran sosiologi mengatur jadwal pertemuan tim pengabdian kepada masyarakat dengan siswa di sekolah dengan mengambil waktu istirahat siswa untuk dijadikan sebagai waktu pelaksanaan kegiatan pengabdian.

d. Guru mata pelajaran sosiologi ikut terlibat dalam pelaksanaan sosialisasi pelatihan penggunaan literasi digital berbasis quick response code $(\mathrm{QRC})$ kepada siswa.

e. Guru mata pelajaran sosiologi ikut terlibat dalam gerakan literasi digital berbasis quick response code (QRC) melalui komitmen untuk menambah variasi literasi digital berbasis quick response code (QRC).

\subsection{Gerakan Literasi Digital Berbasis quick response code (QRC)}

Program pengabdian kepada masyarakat melalui literasi digital berbasis quick response code (QRC) pada mata pelajaran sosiologi akan terus dilakukan oleh tim pengabdi dan guru mata pelajaran sosiologi dengan menambah varian literasi digital berbasis quick response code (QRC) bukan hanya pada buku ajar dan modul mata pelajaran sosiologi namun juga sampai pada LKS siswa, buku referensi, artikel, berita online, blog, youtube, gambar, peta konsep, lagu, video dan lain-lain yang bisa diakses melalui literasi digital berbasis quick response code (QRC).

Literasi digital berbasis quick response code (QRC) sebagai bagian dari gerakan literasi yang dicanangkan oleh pemerintah Kabupaten Bantaeng melalui Dinas Pendidikan dan Kebudayaan, sehingga kegiatan selanjutnya akan dilakukan dalam skala yang lebih besar. Selain itu gerakan literasi merupakan program yang dilakukan oleh pemerintah Kecamatan Bissappu dan gerakan literasi di tingkat tingkat Sekolah. Sehingga program pengabdian kepada masyarakat melalui literasi digital berbasis quick response code (QRC) pada mata pelajaran sosiologi memiliki kontinuitas untuk pengembangan proses pembelajaran yang lebih baik untuk mata pelajaran sosiologi di jenjang sekolah menengah atas (SMA) atau pada madrasah Aliyah (MA).

Program pengabdian kepada masyarakat tersebut juga sebagai bentuk gerakan literasi untuk guru dan siswa pada masa pandemic covid 19 (Sutrisna, 2020) dan masa new normal. Dengan gerakan literasi dapat menciptakan pola pikir yang kreatif dalam diri siswa di masa pandemic covid 19 (Sutrisna, 2020). Dengan quick response code (QRC) guru mudah memberikan buku mata pelajaran sosiologi atau modul mata pelajaran sosiologi kepada siswa, dengan hanya melakukan proses scanning dan pemindaian data melalui media dari kamera handphone yang dimiliki oleh setiap siswa (Anastasia, Istiadi, dan Hidayat, 2010). Literasi digital sangat penting untuk menunjang proses pembelajaran mata pelajaran sosiologi baik untuk guru maupun untuk siswa selama masa belajar di rumah maupun belajar di sekolah, sehingga literasi digital berbasis quick response code (QRC) untuk guru mata pelajaran sosiologi dapat memberikan keterampilan kepada kelompok guru mata pelajaran sosiologi bukan hanya mampu menggunakan literasi digital quick response code (QRC) dan juga mampu membuat literasi digital quick response code (QRC) pada mata pelajaran sosiologi dengan variasi materi yang berbeda. Selain 
Andi Agustang, Suardi Suardi, Andi Dody Putra Agustang, Shermina Oruh Pemberdayaan Guru Mata Pelajaran Sosiologi Melalui Literasi Digital Berbasis Quick Response Code di Kecamatan Bissappu Kabupaten Bantaeng

itu juga untuk memberikan kesadaran kepada guru untuk menciptakan gerakan literasi digital berbasis quick response code (QRC) untuk kelompok mata pelajaran sosiologi karena pada kegiatan pengabdian kepada masyarakat yang dilakukan guru-guru mata pelajaran sosiologi sudah memiliki komitmen dalam melakukan gerakan penggunaan literasi digital berbasis quick response code (QRC).

Penggunaan quick response code (QRC) sangat efektif digunakan dalam proses pembelajaran mata pelajaran sosiologi, meskipun penggunaan dalam mata pelajaran sosiologi masih dianggap sesuatu yang baru untuk guru maupun siswa, padahal quick response code (QRC) sangat bagus digunakan untuk pembelajaran (Bonifácio, 2012) pada mata pelajaran apapun termasuk mata pelajaran sosiologi dalam suatu sistem pembelajaran di sekolah (Lai et al., 2013), ataupun implementasi proses pendidikan di sekolah (C. Law \& So, 2010), bisa juga mengkonfirmasi kehadiran siswa di sekolah (Masalha \& Hirzallah, 2014), atau mendesain ulang materi pelajaran (Durak et al., 2016), bahkan semua untuk pembelajaran di kelas (Rikala \& Kankaanranta, 2012), atau berbagai kegiatan pembelajaran di sekolah (Nagla et al., 2017) seperti kegiatan kurikuler atau ekstrakurikuler. Diberbagai negara bahkan digunakan menjaga dokumen pendidikan, keamanan dan menghindari duplikasi (Goyal et al., 2016), melihat dan merekam kehadiran siswa (Baban, 2014), menonton klip video keterampilan oleh pelajar (Tracey et al., 2013), pembelajaran mata kuliah di Perguruan Tinggi (Traser et al., 2015). Penggunaan literasi digital berbasis quick response code $(\mathrm{QRC})$ pada mata pelajaran sosiologi telah mendorong motivasi siswa dalam proses pembelajaran (R. Law, 2012), pembelajaran aktif untuk siswa yang dapat meningkatkan keterlibatan siswa dan rasa ingin tahu siswa untuk belajar mata pelajaran sosiologi (Somerall \& Roche, 2020), karena dengan literasi digital berbasis quick response code (QRC) pada mata pelajaran sosiologi mampu penyediaan informasi buku mata pelajaran sosiologi maupun modul mata pelajaran sosiologi, ataupun menghubungkan berbagai media (Mawaddah et al., 2018). Penggunaan literasi digital berbasis quick response code (QRC) pada mata pelajaran sosiologi oleh guru dapat meningkatkan pengetahuan siswa (Patil, 2020), karena memudahkan siswa belajar dan memudahkan siswa melihat halaman web (Susono \& Shimomura, 2006) hanya dengan melakukan proses scan barcode buku mata pelajaran sosiologi maupun modul mata pelajaran sosiologi. Sehingga literasi digital berbasis quick response code (QRC) pada mata pelajaran sosiologi sangat membantu guru dalam menyampaikan informasi atau materi pelajaran kepada siswa (Abualnadi et al., 2018).

\section{Kesimpulan}

Kegiatan literasi digital berbasis quick response code (QRC) untuk kelompok guru mata pelajaran Sosiologi dilakukan dalam beberapa tahapan yaitu tahap penyediaan materi, tahap sosialisasi, tahap penyampaian materi, tahap pembagian literasi digital berbasis quick response code (QRC) dan tahap gerakan literasi digital berbasis quick response code (QRC). Sedangkan kegiatan pelatihan literasi digital berbasis quick response code (QRC) kepada siswa terdiri dari tahap pembuatan jadwal pertemuan, tahap penyampaian materi, tahap penggunaan literasi digital berbasis quick response code (QRC), tahap pembagian literasi digital berbasis quick response code (QRC) dan tahap gerakan literasi digital berbasis quick response code (QRC). Program kegiatan mendapatkan respon positif dari semua kalangan yang terlibat dalam program kegiatan mulai dari pemerintah, guru mata pelajaran sosiologi, siswa, bahkan guru mata pelajaran lain. Partisipasi guru mata pelajaran dilakukan sejak perencanaan kegiatan, pelaksanaan kegiatan sampai akhir kegiatan, melalui keikutsertaan dalam kegiatan, memberikan masukan, pengaturan jadwal, keterlibatan dalam sosialisasi dan gerakan literasi digital quick response code $(\mathrm{QRC})$. Literasi digital berbasis quick response code $(\mathrm{QRC})$ sebagai bagian dari gerakan literasi yang dicanangkan oleh pemerintah Kabupaten Bantaeng di tingkat Kecamatan dan dan di tingkat sekolah. Terimakasih banyak penulis sampaikan kepada Universitas Negeri Makassar melalui Lembaga Penelitian dan Pengabdian Kepada Masyarakat memberikan dana PNBP untuk pelaksanaan kegiatan pengabdian kepada masyarakat Tahun 2021. 
Andi Agustang, Suardi Suardi, Andi Dody Putra Agustang, Shermina Oruh Pemberdayaan Guru Mata Pelajaran Sosiologi Melalui Literasi Digital Berbasis Quick Response Code di Kecamatan Bissappu Kabupaten Bantaeng

\section{Daftar Pustaka}

Abualnadi, D., Al-salaymeh, A., Sukkar, G. AL, \& Hawa, M. (2018). The Eurasia Proceedings of Educational \& Social Sciences (EPESS) The Eurasia Proceedings of Educational Using QR Codes for Improving the Educational Process of Students with Hearing Loss. \& Social Sciences (EPESS), 11(1), 116-122. www.isres.org

Baban, M. H. M. (2014). Attendance Checking System Using QRC For Students At The University Of Sulaimaniyah. Journal of Mathematics and Computer Science, 10(3), 189-198. https://doi.org/10.22436/jmcs.010.03.04

Bonifácio, V. D. B. (2012). QR-coded audio periodic table of the elements: A mobile-learning tool. Journal of Chemical Education, 89(4), 552-554. https://doi.org/10.1021/ed200541e

Dental, S. (2017). QR Codes - an Essential Tool for Orthodontist's Smartphone. SCIFED Publisher, $1(1), \quad 1-5 . \quad \mathrm{http}: / / \mathrm{www}$.scifedpublishers.com/open-access/qr-codes-an-essential-tool-fororthodontists-smartphone.pdf

Durak, G., Ozkeskin, E. E., \& Ataizi, M. (2016). Qr Codes in Education and Communication. Turkish Online Journal of Distance Education, 1(1), 42-58. https://doi.org/10.17718/tojde.89156

Febliza, A., \& Okatariani, O. (2020). Pengembangan Instrumen Literasi Digital Sekolah, Siswa dan Guru. Jurnal Pendidikan Kimia Universitas Riau, 5(1), 1. https://doi.org/10.33578/jpk$\underline{\text { unri.v5i1.7776 }}$

Goyal, S., Yadav, S., \& Mathuria, M. (2016). Exploring concept of QR code and its benefits in digital education system. 2016 International Conference on Advances in Computing, Communications and Informatics, ICACCI 2016, 1141-1147. https://doi.org/10.1109/ICACCI.2016.7732198

Kurnia, N., Wendratama, E., Adiputra, W. M., \& Poerwaningtias, I. (2019). Literasi Digital Keluarga: Teori dan Praktik Pendampingan Orangtua. Yogyakarta: Gadjah Mada University Press.

Lai, H. C., Chang, C. Y., Wen-Shiane, L., Fan, Y. L., \& Wu, Y. T. (2013). The implementation of mobile learning in outdoor education: Application of QR codes. British Journal of Educational Technology, 44(2), 57-62. https://doi.org/10.1111/j.1467-8535.2012.01343.x

Law, C., \& So, S. (2010). QR Codes in Education. Journal of Educational Technology Development and Exchange, 3(1), 24-26. https://doi.org/10.18785/jetde.0301.0

Law, R. (2012). Using quick response codes for student interaction during lectures. Annual Conference on Innovation and Technology in Computer Science Education, ITiCSE, 401. https://doi.org/10.1145/2325296.2325417

Masalha, F., \& Hirzallah, N. (2014). A Students Attendance System Using QR Code. International Journal of Advanced Computer Science and Applications, 5(3), 1-10. https://doi.org/10.14569/ijacsa.2014.050310

Mawaddah, K., Kusuma Wardani, L., \& Sunarmi, D. (2018). Pengembangan Media Interaktif Berbantuan QR-CODE Pada Materi Tumbuhan Paku Untuk Siswa SMA. Jurnal Pendidikan Biologi, 9(1), 23-30. https://doi.org/10.17977/UM052V9I1P23-30

Nagla, A., Ieda, M. S., \& Shaljan, A. (2017). Pre-service Teachers' Perception of Quick Response (QR) Code integration in Classroom Activities. Turkish Online Journal of Educational Technology, 16(1), 93-100. https://eric.ed.gov/?id=EJ1124922

Nursalam, N., Suardi, S., Syarifuddin, S., Mutiara, I. A., \& Herdianty, R. (2020). Pemberdayaan Masyarakat Desa Melalui Literasi Digital Berbasis CR Code di Desa Bonto Jai Kecamatan Bissappu Kabupaten Bantaeng. Jurnal Pengabdian Pada Masyarakat Membangun Negeri, 4(2), 228-238.

Patil, V. V. (2020). Application Of Quick Response [ QR ] Code For Digitalization of Plant Taxonomy . Journal of Information and Computational Science, 10(1), 1287-1293.

Puspitaningdyah, R. W. (2012). Penduduk Dan Pengguna Internet Negara-Negara Di Dunia. Ekonomi, 41-48. file:///C:/Users/ppknu/Downloads/38-Article Text-116-1-10-20130418.pdf

Rikala, J., \& Kankaanranta, M. (2012). The use of Quick Response codes in the classroom. CEUR Workshop Proceedings, 955(October 2012), 148-155. 
Somerall, W. E., \& Roche, C. C. (2020). The ABCs of STIs: Promoting student learning using QR codes. Journal of Nursing Education, 59(5), 299. https://doi.org/10.3928/01484834-20200422$\underline{15}$

Sugiyono. (2011). Metode penelitian kombinasi (mixed methods). Bandung: Alfabeta.

Susono, H., \& Shimomura, T. (2006). Using Mobile Phones and QR Codes for Formative Class Assessment. Current Developments in Technology-Assisted Education, 2, 1006-1010. http://citeseerx.ist.psu.edu/viewdoc/download?doi=10.1.1.129.8360\&rep=rep1\&type=pdf

Sutrisna, I. P. G. (2020). Gerakan Literasi Digital Pada Masa Pandemi Covid-19. Stilistika: Jurnal Pendidikan Bahasa Dan Seni, 8(2), 268-283. https://doi.org/10.5281/zenodo.3884420

Tracey, D. L., DiStefano, T. P., Morris-Hackett, N., \& Steefel, L. (2013). Using quick response codes to facilitate self-directed learning in a nursing skills laboratory. Journal of Nursing Education, 52(11), 664. https://doi.org/10.3928/01484834-20131022-12

Traser, C. J., Hoffman, L. A., Seifert, M. F., \& Wilson, A. B. (2015). Investigating the use of quick response codes in the gross anatomy laboratory. Anatomical Sciences Education, 8(5), 421-428. https://doi.org/10.1002/ase.1499

Wicaksono, D., Rakhmawati, Y., \& Suryandari, N. (2019). Prosiding Seminar Nasional Teknologi dan
Sains
(SNasTekS.
E-Prosiding
SNasTekS,
l(1),
9-14.

https://journal.unusida.ac.id/index.php/snts/article/view/70

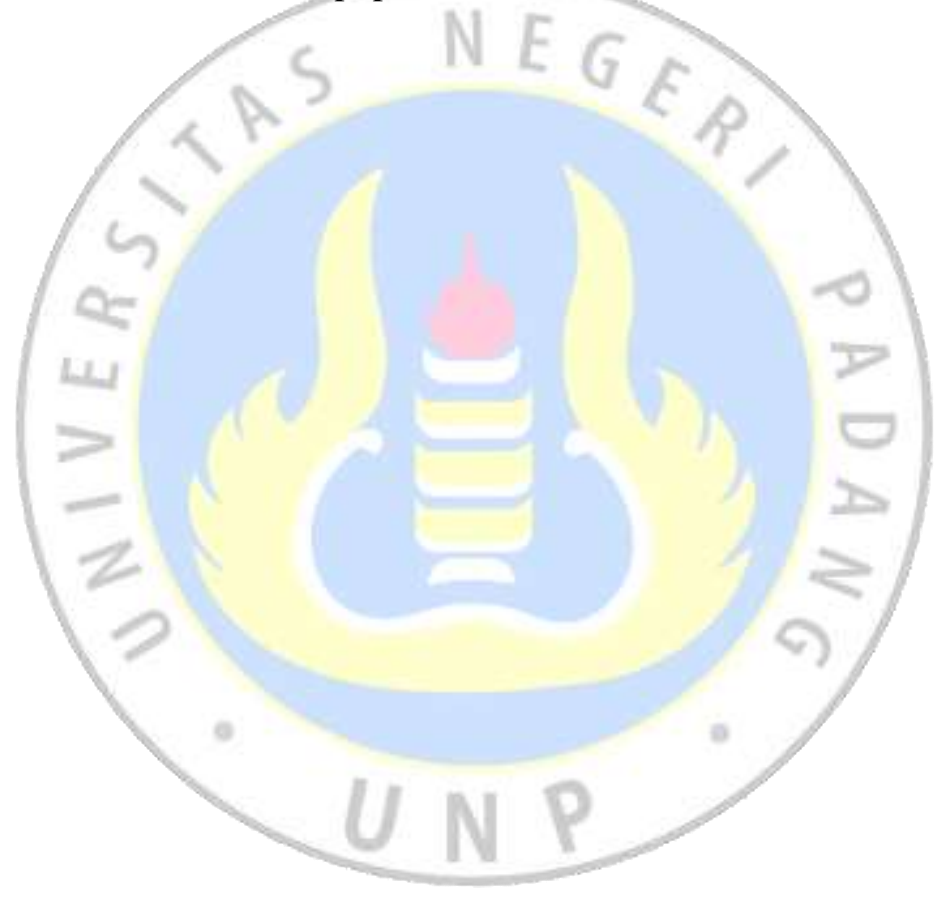

